\title{
O diário de Flora
}

Teresa Malatian

O Boudoir Diary, escrito em 1915, consiste numa narrativa construída em Londres e nos Estados Unidos por Flora de Oliveira Lima, esposa de Manoel de Oliveira Lima. Tendo sido durante grande parte de sua vida secretária de seu marido, acompanhou de perto sua trajetória e partilhou posicionamentos políticos por ele assumidos, participando de rodas de intelectuais, diplomatas e políticos no Brasil e na Europa no contexto da belle époque. Não obstante, percebe-se no seu diário a presença de uma narradora com interesses próprios, que construiu uma interpretação no feminino de muitas dessas vivências. Trata-se não apenas de uma narrativa da vida de Flora mas também dos acontecimentos da vida do casal, registrados através do filtro seletivo da narradora. Nele a preocupação com a imagem pública se impõe ao desvendar da vida íntima, com a certeza de que esse registro seria lido um dia, tanto que foi conservado na Oliveira Lima Library, entre os inúmeros papéis do casal, único exemplar de uma intencional construção do eu.

As memórias em seus diversos registros (orais, escritos, festas, monumentos, gestos, rituais) reúnem lembranças construídas por um grupo, expressando valores e regras de ação portadoras de relações de poder material e simbólico. Nesse sentido, os diários constituem um "capital de lembranças" de grupos, traduzem uma dimensão temporal, espacial e social da cultura. A análise de um documento íntimo, como o Boudoir Diary, contribui portanto para a compreensão dos procedimentos de apropriação seletiva do passado e sobretudo do presente dos narradores, considerando-se que diários apresentam um dado ordenamento, cuja coerência aparente remete á organização dos grupos e aos quadros que sustentam o conjunto, conferindo-lhe um sentido.

Caracterizam-se os diários femininos por serem arquivos em geral pouco preservados, sujeitos à destruição mesmo ainda em vida de suas autoras, e no entanto, de grande interesse para a História pela riqueza de seus conteúdos. Na França, por exemplo, no século XIX e início do XX, esses registros íntimos eram comuns e faziam parte da cultura das moças solteiras, sendo recomendados por professores e educadores como uma forma de controle de si. Os diários escritos naquela época constituem não apenas produtos da moral vigente, mas também indicadores de movimentos de contestação e emancipação das mulheres mediante práticas de elaboração do eu. Tal característica de sua produção justifica a ausência de temas como sexualidade, mudanças físicas, emoções fortes, paixões, de modo que esses registros atenderam a uma função social específica, que consistia na disciplinarização das moças para torná-las boas esposas e mães cristãs, segundo os códigos da época. Assim como as cartas, tais documentos privados são construídos segundo normas específicas, que no caso do Boudoir Diary evidenciam códigos vitorianos burgueses de relações entre público e privado, coletivo e individual, ostensivo e íntimo, masculino e feminino, combinados num jogo de ocultamento / revelação, normativos da construção e apresentação de uma imagem pessoal, extremamente 
adequados ao conceito de privacy $^{2}$. Compreende-se assim a adequação sugestiva do tipo de suporte escolhido para o registro, uma caderneta impressa cujo título de imediato remete ao espaço íntimo do toucador, da saleta reservada de um mundo essencialmente feminino, destinado ao arranjo pessoal da mulher, no qual o espelho tem papel fundamental. Espelho onde a autora se olha, se vê e lhe devolve uma imagem a ser partilhada com o leitor.

Iniciado em Londres(1/1/1915) e encerrado em Worcester, Massachussets (20/ 12/1915), o diário foi inteiramente escrito em inglês, por razões não explicitadas pela autora. A escolha sugere ambientação da personagem e construção de um eu adequado à fase de sua vida, após a aposentadoria do marido do serviço diplomático e do estabelecimento do casal em Londres, em 1914, onde esperava residir definitivamente. Outra hipótese indicaria o texto como sinal de refinamento e superação do meio intelectual acanhado dos engenhos onde a autora nascera e vivera infância e juventude.

O diário começa, como muitas vezes ocorre, com uma resolução de ano novo e a informação de não ter sido essa a primeira vez em que Flora tomou tal iniciativa. Essa informação permite elucidar aspectos da estrutura da narrativa, a qual parece recuperar informações anteriormente registradas.

O que teria motivado a escrita desse diário? Vários dados permitem construir um contexto motivador, no qual a Primeira Guerra Mundial, a constatação da transitoriedade e fragilidade do instante, a possibilidade da morte são evidentes. O início de uma nova fase da vida com o estabelecimento do casal em Londres fora praticamente abortado em razão dos posicionamentos políticos pró-Alemanha assumidos por Oliveira Lima durante a guerra. Esses elementos estão ali presentes, pois o texto tem início com a referência à perda do transatlântico "H.M.S. Formidable" pela Inglaterra, evento que merece a pergunta inicial de Flora : "How long will it last?" Por trás desta pergunta, subsiste oculta a indagação: $\mathrm{O}$ que você leitor quer que eu conte da minha vida?

Desde o início, uma apresentação mais detalhada da autora se impõe à análise do seu registro de vida. Flora Cavalcanti de Albuquerque (1893-1940) era a filha mais velha ${ }^{3}$ de Henriqueta de Barros Lins (1842-1922) e Manuel Cavalcanti de Albuquerque (1835-1899), senhores do engenho Cachoeirinha, situado no município de Escada, na Zona da Mata pernambucana. Pelo lado materno, descendia de Henrique Marques Lins, senhor do engenho Matapiruma e visconde de Utinga, de largas posses e descendência numerosa. Ao escrever seu diário, Flora não apenas se inseriu nas práticas de registro do eu vigentes desde o século XIX, mas deu continuidade a uma tradição memorialística da família, de acordo com os hábitos da oligarquia açucareira de Pernambuco. Seu avô, o visconde de Utinga, havia deixado um manuscrito, o "Livrinho importante para minha casa", secundado pelo genro Ambrósio da Cunha Cavalcanti ("Lembranças e apontamentos para meus filhos"), pelo filho Marcionílio da Silveira Lins ("Livro de minhas prezadas recordações e lembranças" ) e pela neta Teudelina Cavalcanti Lins ("Caderno e lembranças") ${ }^{4}$. A especificidade deste Boudoir Diary consiste sobretudo em não se ater a uma crônica de família ou a uma genealogia, mas em constituir um relato autobiográfico que condensa a história de uma vida narrada na primeira pessoa, inserida num grupo específico da diplomacia e da intelectualidade radicado em Londres, embora com raízes em diversos países. 
Os biógrafos de Flora ressaltam sua origem de sinhazinha do município de Vitória de Santo Antão. De fato, nascera no engenho Castanha Grande, município de São Luís do Quitunde, em Alagoas, a 26 de agosto de 1863, mas ainda menina viera para Pernambuco, onde crescera. Passou a infância no engenho Cachoeirinha, de propriedade de seu pai, o Coronel Minô, "homem de boa cultura humanista, bem educado e figura representativa do clã açucareiro", totalmente voltado para o cultivo da cana, tanto que seus interesses o levaram a procurar causas de doenças que dizimavam os canaviais. Fez experiências com a germinação da semente da flecha da cana caiana, variedade que recebeu seu nome. Foi chefe do partido liberal em sua comarca mas não ocupou cargos públicos. ${ }^{5}$

Preocupado com a educação da prole numerosa, Manuel Cavalcanti de Albuquerque contratou uma educadora inglesa, Mrs. Rawlinson, que se encarregou de seus 13 filhos, preparando-os para cursarem o ginásio oficial ${ }^{6}$. A vida de Flora tomou porém um rumo um pouco diferente em relação ao de outras moças de sua condição social, na época. Mudou-se com os irmãos mais velhos, Artur e Baltazar para o Recife, onde se instalaram num casarão da avó, o Sítio dos Quatro Leões, em Fernandes Vieira, para que os rapazes cursassem o ginásio. Ao contrário dos irmãos, Flora estudou com um professor particular, Jesuíno Lopes de Miranda, prestando os exames finais na década de 80, sendo aprovada com brilhantismo.

Nessa época, acometida de tifo, foi enviada em viagem de cura a Paris, com o irmão Baltazar, em 1878. Tinha então 15 anos de idade. A bordo, o primeiro romance, com um médico argentino, sem continuidade. De volta ao engenho Cachoeirinha, novo romance, desta vez caminhando para noivado, com José Maximino de Souza Leão, que acabou rompido por razões apresentadas publicamente como decorrência do desinteresse da noiva, apesar da fortuna do pretendente ${ }^{7}$. Frustradas as duas tentativas de chegar ao casamento, o mercado matrimonial reduzia-se para uma jovem daquele meio social, onde os enlaces costumavam ocorrer na idade entre 15 e 18 anos. Filha mais velha da família, Flora tornava-se "moça-velha", para quem o magistério passou a ser um destino adequado. Voltando a residir no Recife, foi então convidada por Mrs. Rawlinson para lecionar no colégio por ela mantido no Poço da Panela, assumindo um trabalho fora do círculo doméstico mas adequado ao destino de gênero por prolongar no espaço público funções da esfera da reprodução. Além desse trabalho, também ministrava aulas particulares de inglês. No colégio os métodos de ensino eram rígidos, e seus alunos, exclusivamente filhos da colônia inglesa radicada na cidade. Ali os ingleses eram moradores destacados e mantinham um estilo de vida próprio. ${ }^{8}$

O casamento constituiu um momento de ruptura com o mundo dos engenhos e da família patriarcal, criando para Flora a oportunidade de uma nova vida no exterior, com viagens, festas, atividades intelectuais e políticas. Não existem registros memorialísticos acerca do seu encontro com Oliveira Lima. Em suas Memórias ${ }^{9}$, ele pouco se expandiu sobre sentimentos, afeições, namoros, para não dizer que os suprimiu totalmente; o conhecimento que se tem do casamento começa com o encontro nebuloso que tiveram no Recife, quando Oliveira Lima ali esteve, de retorno do Rio de Janeiro, onde obtivera a nomeação para o cargo de secretário de legação em Lisboa. Em dezembro de 1890, desembarcou naquela cidade, onde moravam parentes e amigos; o casa- 
mento ocorreu em janeiro de 1891, após compromisso de noivado registrado em suas Memórias, com data do início desse mesmo ano.O casamento do jovem recém nomeado secretário de legação com a professorinha nada mais foi que um arranjo, conforme padrões da época, sem grandes arrebatamentos, não faltando ao enredo a habitual conspiração familiar para aproximar os jovens. A anuência do pai de Flora foi acompanhada do esclarecimento ao pretendente de que não haveria o dote de praxe para a noiva, circunstância que pode ter dificultado tentativas anteriores de casamento e que talvez indique estratégias matrimoniais de uma família decadente do ponto de vista econômico, pois era praxe a doação, pelo pai da noiva, de adiantamento de parte da herança da filha ao genro. Outra razão plausível seria o desagrado do pai com a realização do casamento, com um jovem residente no exterior e fora do alcance do poder patriarcal:

Com a sinceridade que me caracteriza, julgo do meu dever esclarecer a V.S que, se encontrou em minha filha as qualidades pessoais que exige para sua esposa, há de ter que contentar-se com estas, sem um dote pecuniário que, nas minhas condições atuais de fortuna, sinto extremamente não poder oferecerthe. Tenho sofrido muitos prejuizos na modesta fortuna herdada de meus pais e por mim aumentada, e vendo-me sobrecarregado de numerosa familia, só procuro presentemente proporcionar a meus filhos um bom e honrado meio de vida (... $)^{10}$

Assim colocado, o compromisso provocou a resistência da família de Oliveira Lima, sobretudo de sua mãe, por não contar a noiva com dote apesar da posição social destacada de sua família. A ausência de dote constituía questão melindrosa e foi motivo de negociações, necessitando a família da noiva enviar a Lisboa o irmão mais velho do pretendente, Luís de Oliveira Lima (Lima Gordo), residente em Pernambuco, para fazer valer o compromisso. A busca de união de fortunas ou situações iguais regia os casamentos arranjados na época e nesse sentido o dote da noiva era decisivo por permitir que o jovem casal mantivesse um dado estilo de vida segundo sua posição de origem, mesmo que os rendimentos não fossem suficientes para tanto. Sem dote, a moça corria o risco de permanecer solteira, futuro que estava delineando-se para Flora. Mesmo não sendo rico, Oliveira Lima herdara do pai comerciante alguns bens e a promissora carreira na diplomacia também pesava na cobrança do dote da noiva. Porém esta trazia o capital simbólico dos vínculos sociais e políticos com a poderosa oligarquia açucareira, além da formação adequada ao papel de esposa de jovem diplomata. Afinal o casamento realizou-se por procuração a 15 outubro de 1891, na casa-grande do engenho Cachoeirinha, festejado apenas com um jantar, no qual a ausência do noivo era o ponto mais atraente. Após a cerimônia, Flora embarcou com Mrs. Rawlinson para Lisboa, ao encontro do marido, trazendo consigo carta do pai endereçada a ele, na qual estavam definidos os papéis que se esperava ela fosse cumprir:

Peģo a Deus que sejam felizes, que minha querida filha seja uma companbeira desvelada e fiel, que tenha sempre junto de si, e que ponba toda sua glória em ser-lhe agradável e dedicada. Eu aqui fico com o coração partido de saudades, separado da filha querida de minha alma! Que ela seja feliz! Numa carta que sua Ex.ma Mãe me dirigiu, dá-me a entender, que, não tendo minha filha posição de fortuna, que the chegue para apresentar-se em grandes reuniões em que V.S. tem de achar-se por força 
do cargo, que ocupa, cumpre-me dizer-lhe que minha filha, educada e criada sem grandezas, sem fausto, contenta-se com a vida modesta, e sem ruido, que seu marido lhe quiser dar, bastando-lhe só o seu afeto, e a sua estima, o que ela espera sempre merecer.

Ela cumprirá com o mais escrupuloso cuidado com todos os seus deveres, domésticos, como dona de casa zelosa e econômica como presumo que deverá ser. Todavia, se minha prezada filha tiver de aparecer alguma vez por acaso em tais reuniões, eu espero que ela não dará motivos a crítica, se se levar em conta o acanhamento natural de uma moça que não está habituada ainda a essas reuniões. ${ }^{11}$

Em Lisboa realizou-se o casamento religioso, em 28 de novembro de 1891 e o casal passou a morar ali,em uma pequena casa, na qual residia também a mãe de Oliveira Lima. Na época, Flora tinha 28 anos de idade, 4 a mais que seu noivo. A partir do casamento, sua vida passou-se na maior parte no exterior do país.

Em que medida a vida de Flora, tal como registrada no diário, atendeu ao destino de gênero? Seu Boudoir Diary constitui um documento precioso para a análise dos papéis que desempenhou enquanto dona de casa, secretária do marido e autora de textos próprios, entre eles sua correspondência pessoal, nos quais se podem vislumbrar formas de aceitação, transgressão ou de superação; frestas e interstícios nos códigos correspondentes aos papéis de gênero. Neste sentido, o diário pode ser o ponto de partida para a compreensão da situação da mulher no período e dos papéis sexuais num determinado espaço de sociabilidade, seus padrões de comportamento, códigos morais, sentimentos, emoções, valores. Enfim, como o diário expressa uma tentativa de construção de uma personalidade independente, de pensamento autônomo e de redefinição dos papéis sociais por Flora. Neste caso, "destino de gênero" diz respeito às "funções relegadas tradicionalmente às mulheres e geralmente circunscritas à esfera da reprodução (cuidado com a casa, os filhos, o marido, etc)"12, ou seja, a posição para uma mulher saída de família patriarcal.

Flora foi privilegiada quanto ao nível de instrução, se considerarmos o padrão brasileiro da época, mesmo para as famílias abastadas do meio pernambucano de onde saiu. Nele a instrução feminina, era limitada a ler, escrever, o conhecimento das quatro operações, doutrina cristã, trabalhos de agulha. Diante da falta de escolas, muitas moças recebiam instrução em suas próprias casas, ministrada por irmãs mais velhas, padres, professoras particulares (em geral européias). Colégios femininos eram raros durante o Império e o acesso ao ensino superior, inexistente para as mulheres. Algumas faziam cursos nas Escolas Normais e se preparavam assim para o magistério primário, que consistia em ocupação tipicamente feminina. Flora teve uma trajetória adequada a este modelo, até seu casamento, porém a partir daí teve necessidade de reelaborar valores e normas, de reinterpretá-los para se adequar ao papel de esposa de diplomata. Era uma mulher "educada", segundo os padrões da época, e estava preparada para assumir essa nova função social. Detestando as tarefas domésticas, sobretudo as de lavagem de roupa (linen), metodicamente realizada às segundas-feiras, estampava no diário seu desagrado com a administração doméstica que parecia ficar totalmente sob seus cuidados, impedindo-a de sair de casa quando queria dar um stroll. O mesmo ocorria com escrita das cartas de housekeeping, sobre as quais assim se manifestava: Isto é o que eu chamo minha literatura, a 
qual certamente não é nenhuma obra de fição mas antes de fato exposição do enorme aborrecimento que é o cuidado com a casa em Londres (30 de de agosto).

Seu desempenho na vida intelectual do marido, apesar de pouco reconhecido, é bastante elucidativo das relações que estabeleceu com os papéis esperados, do modo como os desempenhou e da construção de si que fez no relato. A primeira questão que se impõe é quando exatamente Flora começou a ser secretária do marido? Segundo seu próprio depoimento, já o primeiro livro de Oliveira Lima, - Pernambuco, seu desenvolvimento histórico, publicado em 1895, quatro anos após o casamento, foi ditado a ela pelo historiador. ${ }^{13}$ Desde então, essa parceria não fez mais que crescer e se consolidar numa empresa familiar de grande produção intelectual, instalada na época da escrita do diário na privacidade do home londrino relativamente abastado, como se pode verificar pela existência de criados domésticos (cozinheira, mordomo, costureira). A adequação a este papel, que não estava previsto pelos códigos de condutas das mulheres do seu meio social, destinadas à esfera da reprodução, constitui uma expectativa de contribuir para o projeto familiar de modo peculiar, pois agregou-o aos da presença nos salões e da administração doméstica, ambas extremamente importantes para a manutenção do prestígio social do marido. Nesse sentido, foi valorizado e extremamente utilizado o capital simbólico que agregou à imagem de homem público de Oliveira Lima, seja como diplomata, seja como escritor. Essa é a imagem que procura fixar de si e transmitir ao leitor nas primeiras páginas do seu diário:

Apesar do bom tempo, suficiente para induzir alguém a sair, eu preferi ficar em casa. Eu tenho prazer e muito com que manter-me ocupada em minha casa, assim a menos que eu tenha algum bom motivo para me fazer sair, eu nunca penso em fazế-lo. Minhas manbãs são devotadas a escrever aquilo que Manoel dita, artigos para o Estado de S. Paulo, traducõoes, etc. (10 de fevereiro de 1915).

Pouco a pouco, porém, essa aceitação aparentemente submissa de seu papel de auxiliar do marido vai cedendo lugar na narrativa ao mal-estar causado pelo acúmulo de tarefas, que poderíamos qualificar de dupla jornada. À medida em que os conflitos atingiam a vida do casal nesse tumultuado ano de 1915, as tensões em torno dos papéis iam fazendo-se mais nítidas. No entanto, permanece no leitor a dúvida sobre a extensão desse "devotamento", até que ponto eram reais discordâncias ou se tratava de uma maneira de Flora afirmar seu próprio valor ao salientar o desamparo do marido em seu trabalho intelectual quando desassistido por ela. Sua descrição dos conflitos a colocava numa situação de renúncia aos seus próprios interesses e afazeres domésticos devido ao trabalho de assistente do marido, que dificultava suas saídas de casa, e até mesmo sua vida religiosa, porque " $M$. me manteve escrevendo para ele até que estava muito tarde para me vestir e ir à igreja " (14 de fevereiro).Difícil é, porém, avaliar até que ponto se tratava de rebeldia contra papéis não previstos pela tradicional divisão do trabalho ou um modo de superar seu papel secundário nessa atividade, cuja importância pode ser avaliada pelos registros freqüentes:

Eu nunca menciono o que faço antes do almoģo porque é sempre a mesma coisa: escrever para Emmie em seu ditado. Com freqüência ele está nervoso sobre seu trabalho, descontente porque ele gostaria de 
ter alguém que pudesse estar livre para trabalhar para ele o tempo todo, durante o dia todo e eu não posso provavelmente fazer isso tendo tantas outras coisas por fazer. Esta foi uma dessas manhãs, mas por outro lado eu penso que é uma bênção para ele que eu não possa dar a ele todo o men tempo que ele gostaria de ter para sen ditado on en eston certa de que isso apenas seria man para sua saúde. (26 de março).

Outra passagem revela aspectos manipuladores da personalidade de Flora e sua ascendência sobre o marido, quando se tratava de organizar o trabalho intelectual:

De novo esta manhã Emmie estava muito nervoso, reclamando de que eu não tenho tempo suficiente para seu ditado. Eu fingi estar magoada por ele não ter apreciado men esforço em fazer o melhor para ajudá-lo e ele ficou com pena. Por vezes quando ele começa a trabalhar ele se sente um pouco perdido, tantas coisas ele quer dizerer, sua cabeça cheia de tudo que ele leu sobre diferentes assuntos, as deduções a tirar de tudo isso, e naturalmente ele tem alguma dificuldade em colocar suas idéias juntas, especialmente quando dita. É muito diferente e mais fácil quando ele escreve. Eu suponbo que deve ser a sugestão da pena. Mas depois que ele começa o ditado corre muito fluentemente, quase como se ele estivesse falando. E então ele fica muito satisfeito, um homem bem diferente. (27 de março).

É evidente nos registros a tensão entre os afazeres domésticos, seus próprios interesses (escrever suas próprias cartas) e o trabalho de secretária: a construção do eu caminha para uma identidade dividida entre os papéis tradicionais de dona de casa que deveria encarregar-se da administração doméstica, acompanhar a vida social do marido e auxiliá-lo na produção intelectual. Neste aspecto, a colaboração com Oliveira Lima constituía um trabalho que muito interessava a Flora, que sentia prazer em revelar-se uma interlocutora à altura. O teor da colaboração que ela lhe dava em tudo facilitava essa posição: estava inteirada de toda a sua correspondência, comentava o teor das cartas recebidas, suas opiniões a respeito dos correspondentes, muitas vezes recebendo o ditado das respostas. Trabalhava também na catalogação dos livros da biblioteca, oferecendo ao leitor de seu diário detalhes precisos sobre o modo como o tempo era ocupado pelo casal. Era trabalho conjunto, assim definido : "we worked", portanto sua contribuição era constantemente valorizada nos registros e mesmo que aparentemente subalterna, faziase indispensável ao escritor e tornava sua produção intelectual partilhada em empresa familiar. Em suma, uma vida extremamente organizada, com múltiplas tarefas e afazeres. Se num dado momento a sobrecarga de trabalho acabou levando o casal a cogitar de conseguir uma segunda secretária para ajudar o escritor, Flora resistiu à perda desse papel privilegiado reservando-se o direito de ser "naturalmente a primeira", por seus conhecimentos de gramática, ortografia e, não menos importante, de inglês. Não constitui detalhe irrelevante, pois, o fato de sempre usar o "nós" ao se referir ao trabalho intelectual realizado em conjunto. Até onde ia sua participação nele? Suas opiniões eram ouvidas?

Tudo leva a pensar que o Boudoir Diary expressou grandes resistências ao papel feminino que afastava o destino das mulheres das tentações literárias. Mais do que expor um conflito, o documento é a vívida construção de um eu literário que encontrou esse caminho para expressar sua posição no trabalho intelectual, complementada por uma 
escrita própria de documentos íntimos, sobretudo de cartas. Ele constitui o testemunho do modo como Flora vivenciou e interpretou o casamento, que não lhe deu filhos. Viveu na Europa numa época em que ocorriam avanços femininos na vida pública, as suffragettes faziam campanhas públicas de grande repercussão e a emancipação da mulher era pauta de discussões. Embora não se possa ver nela uma militante feminista, construiu no seu diário um eu questionador dos papéis tradicionais relacionados ao destino de gênero e ao mesmo tempo adotou atitude defensiva perante um leitor que pudesse the cobrar submissão ao papel de dona de casa portadora das virtudes domésticas, daí seu empenho em conciliar no relato dois papéis. Nisto certamente o casamento teve um papel decisivo pois Oliveira Lima, apesar de nascido em Pernambuco, onde residira até os seis anos de idade, era europeu pela formação, tendo residido a maior parte de sua vida na Europa e nos Estados Unidos. Esse fator possibilitou o estabelecimento de uma relação entre o casal bastante distanciada daquela vigente no mundo patriarcal dos engenhos, acrescida pela diferença de idade que dava a Flora uma certa ascendência sobre ele.

Flora tinha seus próprios correspondentes, amizades femininas, de casal e familiares, prática usual entre mulheres do seu meio social, que mantinham intensa atividade epistolar. Para ela, o tempo disponível para essa atividade nunca parecia suficiente, queixava-se de não conseguir escrever suas próprias cartas, devido ao trabalho com "Emmie", expressando a necessidade de uma vida mais autônoma. Suas queixas sobre a impossibilidade de atender a todos os compromissos, bem como a auto-recriminação sobre o hábito de escrever cartas longas ("como se estivesse conversando") podem ser também decodificados como valorização de seus relacionamentos pessoais e afirmação de sua importância perante o volume da correspondência do marido. O que mais afirma nesse relato é o grande prazer que tinha em receber cartas e portanto a necessidade de construir uma individualidade, na qual o trato com as letras, considerado ofício masculino, tivesse um lugar significativo. O mesmo se pode dizer do seu interesse pela política e de seu envolvimento nesse campo.

Nesse sentido, o segundo tema do registro que permite verificar as relações de gênero refere-se à Guerra de 1914-1918. O casal viveu entre 1914 e 1915 em Londres e sofreu as conseqüências das posições germanófilas assumidas por Oliveira Lima na imprensa, sobretudo nos artigos "Ecos da Guerra" publicados em O Estado de S. Paulo, os quais lhe causaram problemas políticos na Inglaterra, tendo sido afinal impedido de lá regressar em 1916, após a estadia nos Estados Unidos, em 1916. Com a constante suspeita da polícia, a casa vigiada, muitas relações com refugiados belgas, o casal enfrentou esse período conturbado com intensa produção intelectual, engajamento em redes de auxílio a refugiados políticos e apoio a movimentos pacifistas. Flora revela então em seus registros novamente a oscilação entre a admiração incondicional ao marido, numa clara postura de casal, e a tentativa de oferecer ao leitor com quem dialoga uma imagem de independência de opiniões. Seus comentários sobre a guerra, que abrem o diário, mantêm-se ao longo de todo o registro, e avisam o leitor desse engajamento compatível com a participação política cada vez maior que as mulheres vinham tendo na Europa e particularmente em Londres, onde o direito de voto era reivindicado: 
"desde que estourou a guerra, quase tudo que ele [Oliveira Lima] faz está relacionado a isso. "Ecos da Guerra" é o título de uma longa série de artigos tratando de cada incidente que ocorre, especialmente no campo diplomático. "As responsabilidades da guerra "é uma outra grande luta na qual a Alemanha entrou arrastada pela ação combinada da diplomacia inglesa e francesa dos últimos 15 anos" (10 de fevereiro).

A casa dos Oliveira Lima em Londres era um local de reunião de uma grupo amplo, de origem diversificada, constituído por intelectuais e diplomatas, muitos estrangeiros, exilados políticos, que mantinham com eles laços de amizade desde a Bélgica. O casal possuía relações consideradas valiosas para os que ali procuravam intermediação para seus problemas, sobretudo para conseguir empregos para os estrangeiros impedidos de retornar ao seu país. Contatos na Legação do Brasil também garantiam certa proteção a brasileiros e facilitavam a vida de muitos. A roda de amigos oferecia também suporte psicológico mútuo naqueles tempos de guerra, amparando os deprimidos e privados de contatos com seu país, com seus familiares. Neste particular, o diário é bastante minucioso na apresentação dos relacionamentos, com a indicação de sua pertença ou não ao grupo, as conversas mantidas, as opiniões políticas.

Nesse ambiente, a relação de Flora com a guerra baseou-se sobretudo nos contatos estabelecidos com o grupo de diplomatas e intelectuais, além de diferentes experiências pessoais. Seu interlocutor constante e maior nesse aspecto era o marido e os artigos que ele escrevia para a imprensa brasileira. Flora valorizava esses artigos sobretudo por abordarem diferentes aspectos da questão: internacional, legal, comercial, histórico:

Eles são particularmente interessantes para mim porque através deles eu tenho uma boa idéia sobre o que está acontecendo sem o incômodo de ler os jornais. É um meio fácil de estar informado sobre este grande evento da história da humanidade, a guerra que parece visar a destruição do trabalho que representa vinte séculos de civilização Cristã (6 de março).

No entanto, em seguida a esse registro, Flora se deu conta do que escrevera pois no dia seguinte suas anotações se reportam novamente à guerra e aí marcou posição, evidenciando o compromisso com a construção do eu e portanto de uma imagem a ser transmitida a um hipotético leitor. Na seqüência, registrava :Eu estava lendo esta tarde, após a saída de M. para o Record Office, um número do jornal socialista Labour Leader e também notas triviais sobre a guerra por Bernard Shaw. Aquelas são minhas idéias.

Vários temas tecem a teia desses registros diários sobre a guerra: as notícias sobre os atos bélicos como o afundamento de navios, o bombardeio de Londres, as chamadas atrocidades alemãs, as dificuldades de abastecimento, as suspeitas de adesão ao inimigo da Inglaterra. O tempo todo, Flora mantém-se germanófila, assumindo claramente a mesma posição do marido e fazendo uma leitura das notícias e de suas vivências a partir deste prisma. A guerra invade sua vida, ocupa sua correspondência (sujeita à censura, como praxe), mobiliza as conversas com as visitas, permeia as relações de amizade. Particularmente vivas são as descrições dos bombardeios de Londres, nas quais a observação à distância dos estragos causados pelas bombas mistura temor e fascínio, sentimento de vingança e de acerto de contas: 
Londres vive agora no terror das bombas dos Zeppelins que são aguardados para apresentar seus cumprimentos aos habitantes da Grande Metrópole a qualquer momento. O povo inglês, graças à sua posição geográfica e à sua poderosa marinha, nunca pensou que seus lares poderiam correr perigos de nenhum tipo, não importando quão terrivel, quão cruel e sangrenta a guerra os empurrasse contra outras nações. Mesmo quando eles começaram esta contra a Alemanha eles nem por um momento pensaram que poderiam ser atacados na Inglaterra e em Londres. Pode-se ver uma grande mudança em seu modo de considerar as coisas desde o primeiro ataque sobre Dover e outros pontos. Eles perderam muito de sua arrogância, a qual deu lugar ao medo (22 de janeiro).

Em abril Flora registra outro ataque alemão sobre diversas cidades da costa leste da Inglaterra como "sensational news". Por terem sido lançadas muitas bombas sem causarem danos, considerava que os alemães poderiam estar testando a distância à qual poderiam voar e "deixar seus cartões de visita" para avisar que um dia iriam de fato bombardear Londres sem serem perturbados em "sua obra de destruição" (16 de abril).

No entanto, à medida em que se intensificaram os bombardeios, que visavam cada vez mais de perto Londres, Flora passou a temer pela sua sobrevivência, registrando o primeiro estrago causado pelos zeppelins a essa cidade, com diversos incêndios nos subúrbios. Comenta até mesmo a censura que a imprensa estabeleceu sobre o noticiário desses eventos,evitando assim alarmar a população. Ressalta que ninguém em Londres pensava ser possível essa nova face da guerra, pois até então o conflito estava no mar e nas trincheiras no continente. O bombardeio do Eastend de Londres trouxe a guerra para perto de sua vida e das pessoas mais próximas, levando Oliveira Lima a fazer seguro da casa. Os noticiários de jornais, sob censura, foram colocados sob suspeita e as mentiras propagadas pela imprensa sobre vitórias dos exércitos ingleses e de seus aliados passaram a ser desacreditadas (27 de agosto). Nesse clima, ocorre o único relato de observação direta de Flora de bombardeio, dos zeppelins com bombas e shells no Nortwest e em London Bridge, atingindo Holborn, Liverpool street e Marble Arch. Em sua casa, todos se refugiaram no porão por ser considerado o lugar mais seguro, tendo Oliveira Lima e o mordomo corrido à rua para ver o ataque, podendo assim testemunhar a queda de algumas bombas nas proximidades da casa. No dia seguinte, Flora foi verificar pessoalmente os estragos, registrando o número de vinte mortos.

Os registros sobre os ataques dos submarinos alemães contra barcos de passageiros ou mercantes tem seu ponto culminante com o espetacular afundamento do transatlântico "Lusitânia" pelos submarinos alemães. Preocupada com a viagem que o casal iria fazer aos Estados Unidos, bem como com a vinda de sua irmã Neomísia a Londres para encarregar-se da casa, Flora teceu comentários angustiados sobre a tragédia, procurando os culpados. Coerente com seu posicionamento germanófilo, procurou isentar os atacantes atribuindo ao almirantado inglês a leviandade de não ter levado a sério as advertências feitas com antecedência de dez dias pelo inimigo. A dimensão da catástrofe (1550 pessoas mortas) levou-a a insistir na responsabilidade do almirantado inglês

por fazer pouco da capacidade dos submarinos alemães e escarnecer de seu poder de fazer qualquer estrago àqueles grandes navios, tão perfeitamente protegidos pela esquadra britânica. É claro que aqueles passageiros americanos tinham maior confiança na proteção britânica do que em qualquer 
coisa na terra, e somente riram para os avisos dados pela Embaixada Alemã em Washington e pelos amigos alemães na Europa, então, pagaram com suas vidas sua fé na Inglaterra (7 de maio).

O ponto crucial do posicionamento de Flora são as notícias sobre as atrocidades alemãs, largamente utilizadas pela contrapropaganda dos aliados. Impedida de verificar pessoalmente, descrendo da imprensa sob censura, Flora se informava junto a amigos e conhecidos para tirar a limpo essas histórias. Seu esquema de referência oscila entre acreditar nas notícias sobre relacionamentos amistosos entre os soldados ingleses e alemães nas trincheiras, com a trégua para o Natal de 1914, e a dúvida sobre a capacidade dos alemães de cometerem atos desumanos. Entre os soldados que confraternizavam saindo das trincheiras, dando apertos de mãos e fumando cigarros juntos, e as notícias de violações, sevícias a seres humanos e animais, Flora se angustiava sem saber onde obter informações seguras. Nem mesmo Oliveira Lima podia socorrê-la pois nesse caso, parece que as fontes de informações eram as mesmas: amigos intelectuais e diplomatas, refugiados, feridos hospitalizados, nenhum testemunhara os atos criminosos. Nestas batalhas da memória, que colocaram em choque versões concorrentes que atendiam os interesses dos diferentes grupos envolvidos na guerra, Flora fez uma escolha. Recusouse a dar aos boatos mais crédito que o de "histoires de paysans" destinadas a provar a crueldade dos alemães. Recusava-se a crer nessas notícias, considerando-as "absolutamente incríveis", meras invenções. Em abril, chocada pelo modo como os ingleses encaravam a guerra, como se ela não existisse, procurava na leitura de jornais franceses (L'Humanité) e alemães, mesmo atrasados, a comparação com os jornais ingleses e assim fundamentar uma atitude mais crítica diante do noticiário.Pôde constatar, com surpresa, que as vitórias inglesas eram também celebradas pelos alemães.

Em sua tentativa de controle da memória e construção de um relato adequado ao grupo de que participava, Flora procurou outros testemunhos autorizados sobre a guerra com pessoas com quem convivia no cotidiano, como caixeiros, fornecedores, prestadores de serviços. Com as visitas, com o amigo reunido em torno da casa de Wetherby Gardens, South Kensington, a guerra era assunto indefectível nas reuniões, e separava os amigos em campos opostos, segundo seus posicionamentos em relação às potências beligerantes. Nesses diálogos, Flora tentava compreender os motivos da guerra, alinhando a cada momento explicações plausíveis: a guerra poderia ter sido evitada, não havia motivo para ela, tratava-se de uma guerra comercial, produto das diplomacias secretas. $\mathrm{O}$ mais longe que foi nessas conjecturas consistiu em afirmar que a guerra fôra motivada basicamente pela oposição entre república e monarquia: De fato o radicalismo juntou as mãos por toda a Europa para esmagar desta forma o governo que tinha feito da Alemanha o unico país onde um progresso sem paralelo havia saído de uma sólida organização (6 de junho). Esquecia-se de que na liderança dos lados opostos havia duas monarquias, a britânica e a alemã.

A escolha do lado alemão causa surpresa, pois o casal havia escolhido fixar residência na Inglaterra, onde a estabilidade política se assentava em sólido parlamentarismo e a família real simbolizava a unidade nacional. Seu posicionamento indica sugestivamente o fascínio que a Alemanha exercia sobre muitos intelectuais na época, inclusive no Brasil, e não pode ser separado do grande progresso material que aquele país alcançou na virada do século, pelo desenvolvimento científico (na historiografia, a construção de 
um paradigma) desde a guerra franco-prussiana. Tais escolhas levaram Flora a polarizar a guerra como evento travado apenas entre as duas potências, deixando de lado as alianças, o imperialismo e as mudanças ocorridas ao longo do conflito, no máximo entendendo a guerra como luta desigual entre a Alemanha e os "Aliados." Nem mesmo suas amizades com os belgas exilados e o fato de ter residido na Bélgica de 1908 a 1912 conseguiu abalar suas convicções germanófilas após a invasão da Bélgica em 1914, que motivou o êxodo de população civil. Sua leitura estava imersa na rivalidade anglo-alemã e pautada pela estrutura dos "faits divers", constituía uma apreensão da realidade segundo o modelo reconhecido pelo grupo e indicativo de sua identidade, na qual a "civilização" e o progresso da Alemanha deveriam ser preservados de contra-memórias.

Aplaudiu vitórias alemãs, como a tomada de Varsóvia: Varsóvia deve cair em mãos dos alemães ou titãs como eles podem bem ser chamados (30 de julho). Essa conquista foi por ela comemorada com a degustação de um vinho especial com amigos, celebrando o avanço da "nação [ que ] estava inteiramente caída, esmagada pelo poderoso inimigo e clamando por paz (1 de agosto). Quando os jornais noticiaram a queda de Varsóvia, registrou: assim os alemães celebraram o primeiro ano da grande guerra (7 de agosto). Ao mesmo tempo em que escolheu o lado alemão, numa atitude perigosa para quem vivia num país do grupo dos "Aliados", engajou-se nos esforços pacifistas, adotando posição humanitária e lamentando a perda de milhares de vidas e a estupidez humana, que considerava sem esperança quando assume caráter coletivo e perde limites:

De outro modo, como se pode explicar uma guerra como esta na qual 99\% dos que estão combatendo tão desesperadamente não têm a menor idéia, en estou certa, de suas razões, boas ou más, que os levaram a esta condição de meros animais selvagens cheios de sede de sangue quando eles não são compelidos por nenbum tipo de ódio e em sua maioria levam vidas comuns como criaturas afetuosas, pacificas (9 de maio).

Não obstante, participou de reunião da International Women's Congress, que trabalhava pela paz e engajou-se na Permanente Peace association, fornecendo listas de brasileiras que poderiam ser convidadas para organizar um ramo brasileiro da associação no Rio de Janeiro, tendo escrito a elas e enviado uma cópia do jornal Towards Permanent Peace. Acompanhou o andamento e registrou diversos comícios pacifistas em Hyde Park, evocando valores cristãos e humanitários para fundamentá-los.Com tais informações e mais ainda, familiarizada com a atividade de Oliveira Lima na imprensa, permitia-se emitir opiniões sobre os "Ecos da Guerra", que considerava os melhores artigos, bons demais para serem publicados nos jornais brasileiros, e o aconselhava a tentar sua publicação em jornais da América do Sul, especialmente Buenos Aires, quando O Estado de São Paulo, pressionado por correntes pró-aliados, reduziu à metade a colaboração de Oliveira Lima para se desmarcar de posicionamento germanófilo. Flora informava aos leitores ter sido chamada a ouvir a leitura, pelo marido, de alguns artigos sobre as responsabilidades da guerra, perante o amigo Bandeira de Melo, com a finalidade de opinar a respeito, "porque poderia ter uma idéia sobre o conjunto". Considerou os artigos esplêndidos e muito convincentes, a lamentar se não fossem publicados, incomparáveis ao que já fora 
escrito sobre a guerra :Eles são tão imparciais, tão plenos do perfeito senso de justiça que não se pode ter senão satisfação ao lê-los.

À medida em que se aproximava a data de sua viagem aos Estados Unidos, mais ansiava pela paz, a qual pensava não ser desejada pelos aliados, interessados apenas em levar adiante sua obra de destruição. ( 7 de setembro).Sem dúvida pesavam nesses posicionamentos as dificuldades que Oliveira Lima estava encontrando em Londres, onde seu mordomo e a cozinheira eram alemães. Receberam diversas visitas da Scotland Yard para esclarecimentos sobre a vida desses empregados.

Em Boston, onde o casal se estabeleceu durante o período em que Oliveira Lima ministrou curso em Harvard (1915-1916), continuam as mesmas estruturas de registro, com a diferença provocada pela distância do palco da guerra. No entanto, ambos manteviveram o posicionamento germanófilo, que continuava criando problemas de relacionamento nos Estados Unidos e que acabou impedindo o casal de entrar novamente na Inglaterra.

A escolha do tema da guerra como diretor da narrativa é de extrema importância para o sentido que a autora deu à sua autobiografia e ao eu construído, bem para a preservação deste documento para a vida do casal, sobretudo para a vida de Oliveira Lima, que sofreu pesadas conseqüências para seus posicionamentos. A carga emocional desse evento não está apenas colocada nos riscos e privações ocorridos durante o conflito, mas em seus desdobramentos posteriores, como o impedimento de retornar à Inglaterra e a necessidade de redirecionr a vida, que culminou com o estabelecimento do casal em Washington, onde terminaram seus dias, ele em 1928, ela em 1940. Nesse sentido, o diário contém o desejo de justificar-se não apenas perante seus contemporâneos, mas para a posteridade, possibilidade da qual Flora possuía aguda percepção e expectativa. Coloca-se pois intencionalmente tanto sua elaboração quanto sua preservação por sua utilidade na manutenção de uma história do eu que é também a história do outro, do casal, onde o eu se confunde e se perde.

$\mathrm{Na}$ sua condição de mulher, acabou escrevendo sobre o chamado "lado menor" da história uma guerra vista da retaguarda, por meio de leituras, relatos de terceiros e reduzido testemunho direto das batalhas. Seria possível outra posição?

É que a construção do eu de uma mulher pelo nascimento era destinada ao mundo privado, da maternidade, do lar, das tarefas domésticas, no máximo acompanhando o marido na vida social intensa do mundo da diplomacia. No entanto, Flora ultrapassou esses destino de gênero ao assumir um lugar distinto do de dona de casa tradicional. Teve um papel importante na carreira do marido, partilhando com ele espaços públicos e privados, onde era de grande visibilidade e participando de suas inquietações. Nela a "virtude doméstica", valorizada tanto pelo meio onde nasceu, a oligarquia pernambucana, quanto na Inglaterra vitoriana, do período a que se refere o diário, encontrou escassa ressonância. Flora não se restringiu ao círculo social doméstico, do trato dos criados e da recepção aos amigos do marido, mas exerceu sobre este grande influência, embora não tivesse produzido obra sua visível, além dos papéis íntimos, dos quais o Boudoir Diary é o exemplar mais significativo. Mesmo exibindo com orgulho sua casa bem situada, mobiliada, organizada e freqüentada, essencial para a manutenção da sociabilidade, sua vida integrou a senhora do lar da família patriarcal do nordeste com a colaboradora do marido. 
Mesmo não recebendo salário, numa produção intelectual que pode ser caracterizada como empresa doméstica, mantinha posição bastante independente, renegando o papel de mulher passiva, dócil, assumindo novos papéis para os quais não fora destinada. A falta de dote foi assim amplamente compensada pelo acúmulo de capital simbólico trazido pela educação que recebera e que a habilitou a desempenhar tal papel. Seu grau de independência é notável, pois saía às ruas sozinha, tinha amizades pessoais, correspondência privada, e o eu que construiu no diário indica a busca constante de opiniões próprias, que encontraram nas práticas epistolares canais de expressão para um desejo de escrita não autorizada pelas relações de gênero com suas implicações, numa vida marcada pelas âncoras da memória da diplomacia e do engenho. Os limites dessa situação podem ser claramente encontrados quando se toca na questão da remuneração: apesar de colaborar com o marido na empresa familiar de produção intelectual, seu trabalho nunca foi remunerado e continuou até a morte do marido dependente dele ,aceitando com aparente naturalidade essa divisão do trabalho naturalizada. Sua condição de mulher, afirmada em palavras e relacionada a atos, revelava-se nas relações de gênero.

\section{Notas}

1 Departamento de História da Faculdade de História, Direito e Serviço Social da UNESP/de Franca.

2 Miclhelle Perrot (org.). História da vida privada da Revolução Francesa à Primeira Guerra. São Paulo: Companhia das Letras, 1991, v.4, pp. 10-11.

3 Os 13 filhos do casal foram: Flora, Eutália, Neomísia, Baltazar, Vitor, Artur, Manuel, Henriqueta, Henrique, Augusto, Antônia, Eudoro e Rafael.

4 Guilherme Auler. Os Utinga. Filhos, netos e bisnetos do senhor de engenho Matapiruma Recife: IAA/Museu do Açúcar, 1963, p. 15.

5 Uma prioridade bem documentada. Recife, 1973 (Conferência na Sociedade Auxiliadora da Agricultura de Pernambuco).

6 Fernando da Cruz Gouvêa. Oliveira Lima: uma biografia. Recife: IAHGP, 1976, 3 v., p.180-184.

7 Idem, p. 185.

8 Uma flor humana. O Jornal, Rio de Janeiro, 13/10/1940. Reproduzido em Diário de Pernambuco, 20/10/1940. 9 M. de Oliveira Lima. Memórias :estas minhas reminiscências... Recife: Sec. Turismo, Cultura e Esportes, 1986.

10 Carta de Manuel Cavalcanti de Albuquerque a Oliveira Lima, Recife, 25/2/1891. Oliveira Lima Library.

11 Carta de Manuel Cavalcanti de Albuquerque a Oliveira Lima, Cachoeirinha, 6/11/1891. Oliveira Lima Library. 12 Anamaria Gonçalves Bueno de Freitas; M. Amália de Almeida Cunha. "Dimensões da condição feminina no final do século XIX, nas páginas do Diário “Minha vida de menina” (1893-1895). Horizontes: Bragança Paulista, n. 19, jan/dez. 2001, pp. 36.

13 Diário de Pernambuco, 18 de setembro de 1930. 


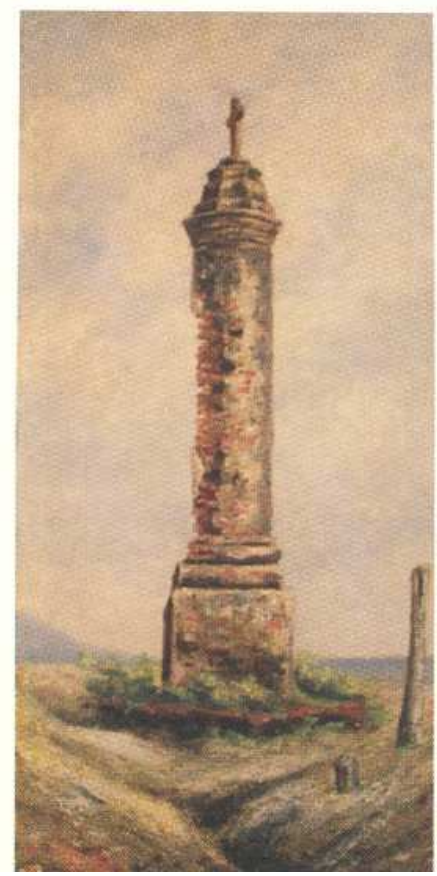

Álvaro de Amorim: A cruz do patrão, 1916, óleo s/ panel, ass./ datado, 59x29 cm.

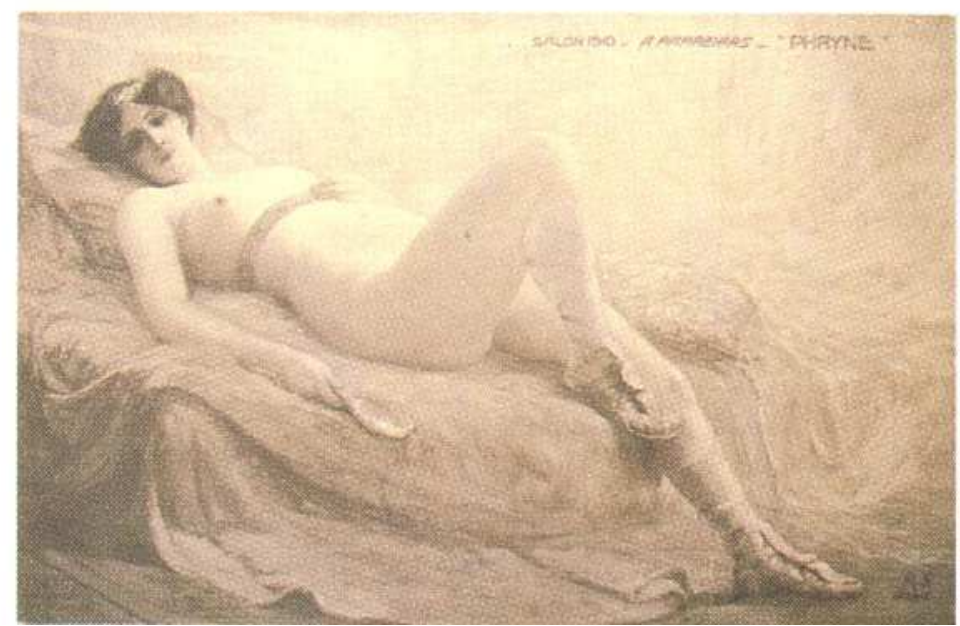

Antonio Parreiras: Frinéia, cartão postal reproduzido a tela. 


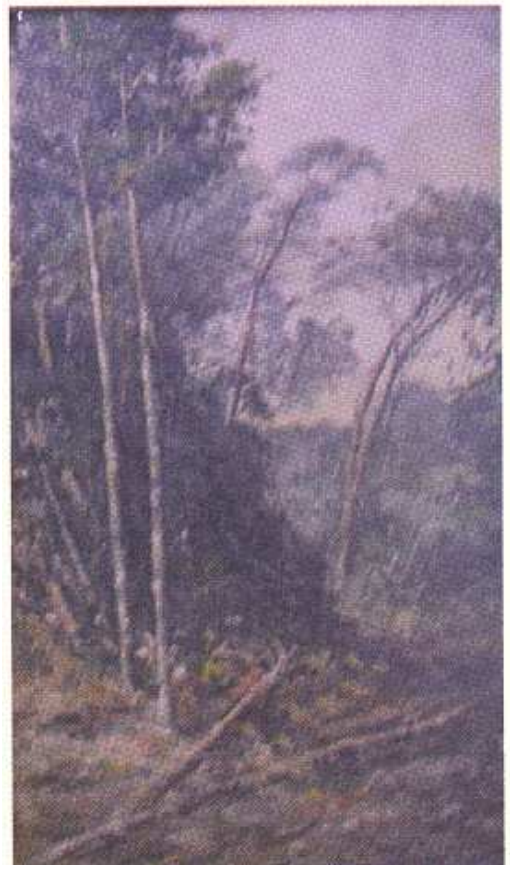

Telles Jr: Pendand. (Derubada de árvores) 1904 óleo s/ tela, 40x31 cm.

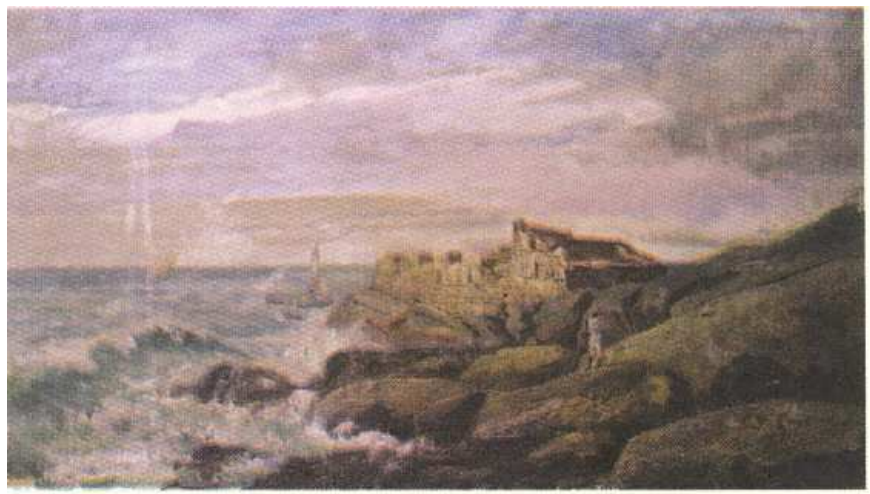

Telles Jr: Forte do Picão: 1906, óleo/Madeira em ass./ datado, 29x50 cm. 


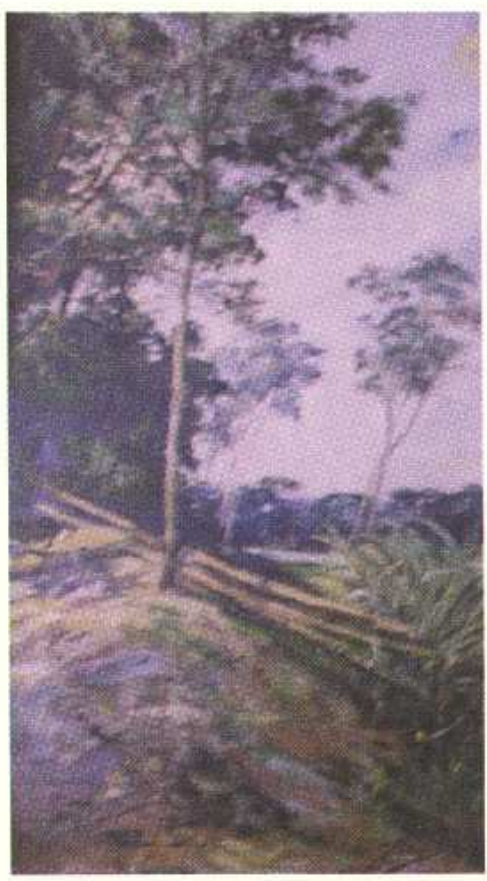

Telles Jr. Pendand. (Derubada de árvores) 1904, óleo s/tela, 40x31 cm.

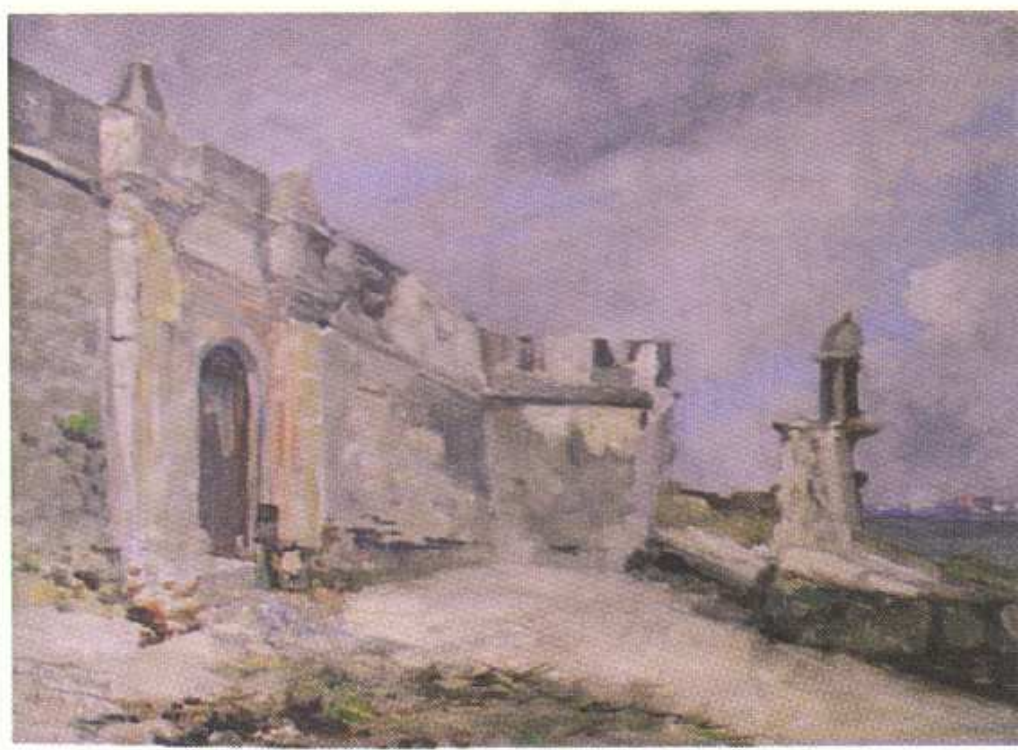

Antonio Parreiras: esboço, (Forte do Buraco) 1917, óleo s/tela, ass/datado, 43×60 cm. 


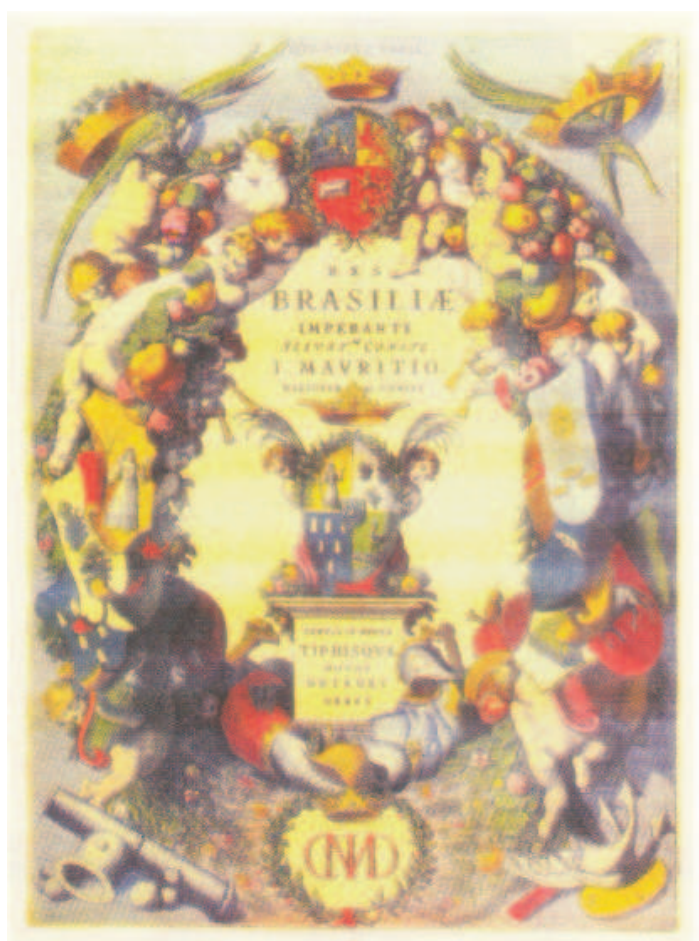

Rerum per octonium in Brasilia (1947)

Barleus

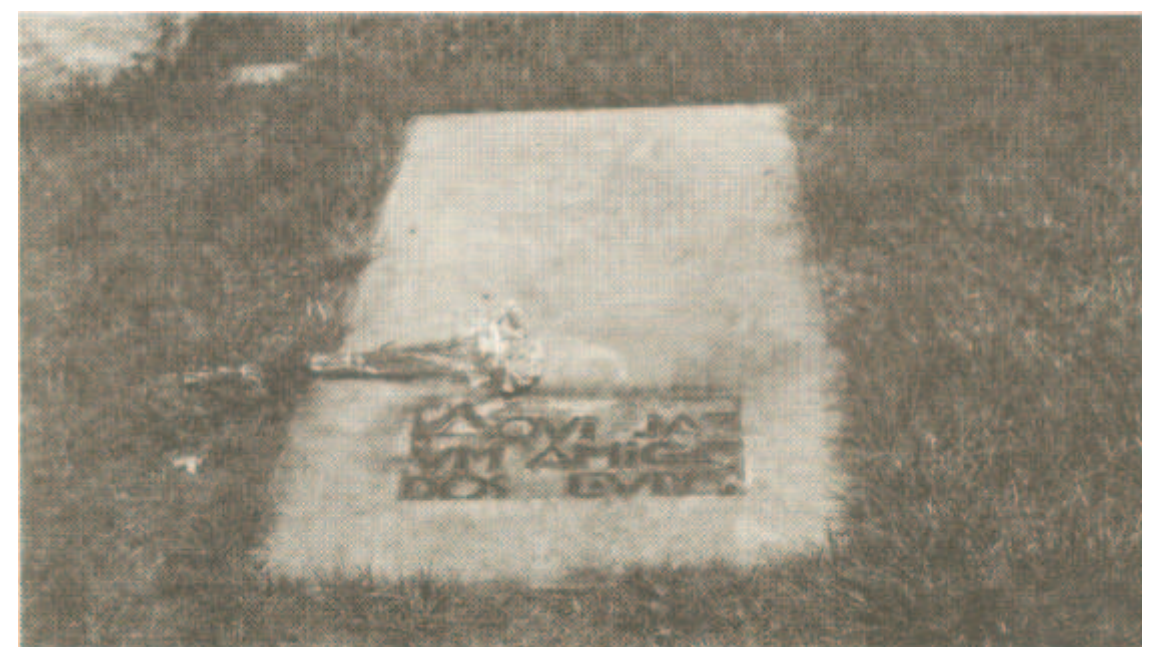

Lápide do túmulo de Manuel de Oliveira Lima no Cemitério Monte das Oliveiras em Washington D.C. Inscrição: Aqui jaz um amigo dos livros. 